\title{
PENGAWASAN DAN KOORDINASI SERTIFIKASI HALAL
}

\author{
Rabiah Z Harahap \\ Fakultas Hukum Universitas Muhammadiyah Sumatera Utara \\ Jl. Kapt. Mukhtar Basri No. 3, Medan - Sumatera Utara \\ Email: rabiahzharahap@gmail.co.id
}

\begin{abstract}
Abstrak
Faktor utama yang menjadi kelemahan konsumen adalah tingkat kesadaran konsumen akan hak-hak mereka yang masih rendah. Ini terutama karena pendidikan konsumen yang rendah. Oleh karena itu undang-undang perlindungan konsumen dimaksudkan sebagai landasan hukum yang kuat bagi lembaga perlindungan konsumen pemerintah dan nonpemerintah untuk melakukan upaya memberdayakan konsumen melalui pembinaan dan pendidikan konsumen. Tulisan ini menggunakan metode penelitian hukum yuridis normatif (penelitian normatif) dengan spesifikasi penelitian deskriptif analitik yang menggunakan data sekunder. Prosedur pengumpulan data adalah dalam bentuk dokumentasi catatan atau kutipan, pencarian literatur hukum, buku-buku dan lain-lain yang berkaitan dengan identifikasi masalah baik offline maupun online yang kemudian dianalisis melalui metode analisis isi (content analysis method) dengan fokus pada masalah bagaimana pengawasan dan koordinasi sertifikasi halal. Hasil penelitian, diketahui bahwa Undang-Undang Perlindungan Konsumen menyatakan bahwa bisnis dilarang memproduksi atau memperdagangkan barang atau jasa yang tidak mengikuti ketentuan produksi halal (Undang-Undang Nomor 23 Tahun 2014 tentang Produk Halal Yang Dijamin).
\end{abstract}

\section{Kata Kunci: Pengawasan, Koordinasi, Sertifikat, Halal}

\section{Abstract}

The main factor which is the weakness of consumers is the level of consumer awareness of their rights is still low. This is mainly due to low consumer education. Therefore the consumer protection law is intended to be a strong legal foundation for government and nongovernmental consumer protection institutions to make efforts to empower consumers through coaching and educating consumers. This writing uses normative juridical legal research methods (normative research) with descriptive analytical research specifications that use secondary data. The procedure of data collection is in the form of documentation of notes or quotations, search of legal literature, books and others related to the identification of problems both offline and online which are then analyzed through the content analysis method with a focus on the issue of how supervision and coordination of halal certification. The results of the study, it is known that the Consumer Protection Act states that businesses are prohibited from producing or trading goods or services that do not follow the provisions of halal production (Law No. 23 of 2014 concerning Guaranteed Halal Products).

\section{Keywords: Supervision, Coordination, Certificate, Halal}

\section{PENDAHULUAN}

Setiap konsumen membutuhkan perlindungan dengan keluarnya undang-undang perlindungan konsumen, maka semakin jelaslah perlindungan hukum bagi konsumen yang mana undang-undang ini sebagai payung bagi konsumen. Hak konsumen yang tertera di dalam pasal 4 huruf 1 Undang-Undang Perlindungan Konsumen Nomor 8 Tahun 1999 (UUPK) yang menyatakan, hak untuk mendapatkan keamanan dan kenyamanan atas pemakaian barang atau jasa. Disini sebagai konsumen kita haruslah mendapatkan keamanan 


\section{DE IFGA LATA}

Jurnal Ilmu Hukum

FAKULTAS HUKUM UMSU
Pengawasan Dan Koordinasi...(Rabiah Z Harahap)

Volume 3 Nomor 1, Januari-Juni 2018, 108-118 DOI: $\underline{\text { https://doi.org/10.30596/dll.v3i1.3145 }}$

dan kenyamanan baik dalam pemakaian ataupun barang atau jasa guna terlindunginya hakhak sebagai konsumen.

Faktor utama yang menjadi kelemahan konsumen adalah tingkat kesadaran konsumen akan haknya masih rendah. Hal ini terutama disebabkan oleh rendahnya pendidikan konsumen. Oleh karena itu undang-undang perlindungan konsumen dimaksudkan menjadi landasan hukum yang kuat bagi pemerintah dan lembaga perlindungan konsumen swadaya masyarakat untuk melakukan upaya pemberdayaan konsumen melalui pembinaan dan pendidikan konsumen.

Makanan adalah segala sesuatu yang berasal dari sumber hayati dan air, baik yang diolah maupun tidak diolah yang diperuntukkan sebagai makanan dan minuman untuk konsumsi manusia, termasuk bahan tambahan pangan, bahan baku pangan dan bahan lain yang digunakan dalam proses penyiapan, pengolahan dan/atau pembuatan makanan dan minuman.

Setiap muslim yang akan melakukan, menggunakan terlebih lagi mengkonsumsi sesuatu produk pangan sangat dituntun oleh agama untuk memastikan terlebih dahulu kehalalan dan keharamannya. Halal berarti boleh sedangkan haram berarti tidak boleh (Qardhawi: 2000).

Di dalam Al-Quran surat Al-Maidah ayat 3 Allah SWT berfirman "Telah diharamkan atas kamu bangkai, darah, daging babi, binatang yang disembelih bukan karena Allah, yang dicekik, yang mati karena dipukul, yang mati karena jatuh dari atas, yang mati karena ditanduk, yang mati karena dimakan binatang buas, kecuali yang sempat kamu sembelih dan diharamkan pula yang disembelih untuk berhala".

Al-Quran mengisaratkan bahwa dalam mengkonsumsi tidak hanya halal saja, namun juga harus thayyib. Hal ini terbukti dengan kata-kata halalan dalam beberapa ayat Al-Quran selalu diikuti dengan kata-kata thayyiban karena tidak semua makanan yang halal akan menjadi thayyib bagi konsumen misalnya penderita penyakit diabetes dalam kondisi sakit dengan kadar gula yang tinggi dalam tubuhnya namun tetap saja dia mengkonsumsi gula. Hal ini tentu saja membahayakan kesehatan konsumen gula tersebut, walaupun gula tersebut halal untuk dikonsumsi namun tidak baik/ thayyib bagi konsumen tersebut.

Kita sebagai konsumen seharusnya setiap membeli produk makanan haruslah memperhatikan terlebih dahulu adalah tanggal kadaluarsa yang biasanya terdapat dalam kemasan tetapi masyarakat kurang memperhatikan labelisasi halal yang menjamin bahwa produk makanan atau minuman yang dibeli halal untuk dikonsumsi.

Bagi konsumen muslim salah satu kenyamanan konsumen dalam menggunakan produk adanya jaminan halal dari pelaku usaha. Hal ini selain senantiasa berkaitan dengan keyakinan agamanya untuk selalu menggunakan dan mengkonsumsi produk halal. Undang-undang perlindungan konsumen dalam rangka perlindungan terhadap konsumen muslim terkait dengan kehalalan suatu produk sebenarnya telah mengaturnya dalam Pasal 8 UUPK mengenai perbuatan yang dilarang bagi pelaku usaha. Pasal 8 ayat 1 huruf H UUPK menyatakan bahwa pelaku usaha dilarang memproduksi dan/atau jasa yang tidak mengikuti ketentuan berproduksi secara halal sebagaimana pernyataan halal yang dicantumkan dalam label.

Pengaturan pemeriksaan sertifikasi halal pada awalnya merupakan kewengan dari kementrian agama. Kementrian agama telah mengeluarkan Keputusan Menteri Agama Nomor 518 Tahun 2001 tentang Pedoman dan Tata Cara Pemeriksaan atau Penetapan Pangan Halal. Selanjutnya ditindaklanjuti dengan Keputusan Menteri Agama Nomor 519 Tahun 2001 
DEIFGA LATA

Jurnal Ilmu Hukum

FAKULTAS HUKUM UMSU
Pengawasan Dan Koordinasi...(Rabiah Z Harahap)

Volume 3 Nomor 1, Januari-Juni 2018, 108-118 DOI: $\underline{\text { https://doi.org/10.30596/dll.v3i1.3145 }}$

tentang lembaga pelaksanaan pemeriksaan pangan halal, yang menunjuk dan mendelegasikan pelaksanaan sertifikasi halal kelembaga pengkajian obat-obatan dan kosmetika majelis ulama Indonesia (LPPOM-MUI).

Masih banyaknya produk yang beredar di masyarakat belum semua terjamin kehalalannya, sehingga memerlukan pengaturan yang komprehensif yang meliputi produk barang dan jasa. Berdasarkan alasan tersebut maka penyelenggaran sertifikasi halal kemudian diatur secara khusus dalam Undang-Undang Nomor 35 tahun 2014 tentang Produk Jaminan Halal (UUPJH). Pemberlakuan UUPJH merupakan salah satu bentuk perlindungan dari negara kepada konsumen muslim Indonesia. Hal ini sesuai dengan Pasal 29 ayat 2 UndangUndang Dasar 1945 mengamanatkan bahwa negara menjamin kemerdekaan tiap-tiap penduduk untuk memeluk agamanya dan kepercayaannya. Untuk menjamin setiap pemeluk agama untuk beribadah dan menjalankan ajaran agamanya, negara berkewajiban memberikan perlindungan dan jaminan tentang kehalalan produk yang dikonsumsi dan digunakan masyarakat, khususnya masyarakat muslim.

Kita sebagai konsumen seharusnya setiap membeli produk makanan haruslah memperhatikan terlebih dahulu tanggal kadaluarsa yang biasanya terdapat dalam kemasan. Tetapi masyarakat kurang memperhatikan labelisasi halal yang menjamin bahwa produk makanan dan minuman yang dibeli halal untuk dikonsumsi.

\section{METODE PENELITIAN}

Penulisan ini menggunakan metode penelitian hukum yuridis normatif (normatif research), yaitu penelitian hukum yang dilakukan dengan cara meneliti bahan pustaka atau data skunder (Seokanto dan Sri Muji, 2003, h. 15). Spesifikasi penelitian dalam penulisan ini berupa penelitian deskriptif analistis. Deskriptif adalah menunjukan komparasi atau hubungan seperangkat data dengan seperangkat data yang lain, dan maksudnya adalah untuk memberikan gambaran, menelaah, menjelaskan dan menganalisis (Soekanto, 1996, h. 63).

Sesuai jenis dan sifat penelitiannya, maka sumber data yang digunakan dalam penulisan ini adalah data skunder yang terdiri dari bahan hukum primer berupa Undang-Undang Nomor 35 Tahun 2014 tentang Produk Halal Jaminan Halal dan Undang-Undang Dasar 1945. Bahan hukum sekunder terdiri dari buku-buku, jurnal ilmiah, makalah dan artikel ilmiah yang dapat memberi penjelasan tentang bahan hukum primer. Bahan hukum tersier berupa Kamus Besar Bahasa Indonesia (KBBI) dan lain sebagainya dalam menemukan defenisi dari istilah-istilah dalam membahas tentang pengawasan dan koordinasi sertifikasi halal.

Prosedur yang digunakan untuk mengumpulkan data dalam penilitian ini berupa dokumentasi yaitu pedoman yang digunakan berupa catatan atau kutipan, penelusuran literatur hukum, buku-buku dan lainnya yang bertalian dengan identifikasi masalah dalam penilitian ini dengan cara offline maupun online. Analisa bahan hukum dilakukan dengan menggunakan metode analisa konten (centent analysis method) yang dilakukan dengan menguraikan materi peristiwa hukum atau produk hukum secara rinci guna memudahkan interpretasi dalam pembahasan (Marzuki, 2011, h. 171).

\section{PEMBAHASAN}

\section{Pengawasan dan Koordinasi Sertifikasi Halal}

\section{Kewajiban Sertifikat Halal}




\section{DE IFGA LATA}

Jurnal Ilmu Hukum

FAKULTAS HUKUM UMSU
Pengawasan Dan Koordinasi...(Rabiah Z Harahap)

Volume 3 Nomor 1, Januari-Juni 2018, 108-118 DOI: $\underline{\text { https://doi.org/10.30596/dll.v3i1.3145 }}$

Terkait dengan kehalalan suatu produk Undang-Undang Nomor 8 Tahun 1999 Tentang Perlindungan Konsumen menyatakan bahwa pelaku usaha dilarang memproduksi dan/ atau memperdagangkan barang atau jasa yang tidak mengikuti ketentuan berproduksi secara halal, sebagaimana pernyataan 'halal' yang dicantumkan dalam label. Keharusan adanya keterangan halal dalam suatu produk dapat dilihat dalam Undang-Undang Nomor 23 Tahun 2014 Tentang Jaminan Produk Halal yang termasuk produk halal adalah barang atau jasa yang terkait dengan makanan, minuman, obat, kosmetik, produk kimiawi, produk biologi, produk rekayasa genetik, serta barang gunaan yang dipakai, digunakan atau dimanfaatkan oleh masyarakat. Yang dimaksud produk halal adalah produk yang telah dinyatakan halal sesuai dengan syariat Islam.

Undang-undang produk halal telah mengatur secara jelas bahwa produk yang masuk, beredar, dan diperdagangkan di wilayah Indonesia wajib bersertifikasi halal. Jadi memang pada dasarnya jika produk yang dijual tersebut adalah halal, maka wajib bersertifikat halal. Ada beberapa kewajiban bagi pelaku usaha yang mengajukan permohonan sertifikat halal dan setelah memperoleh sertifikat tersebut, pelaku usaha yang mengajukan permohonan sertifikat halal wajib:

1) Memberikan informasi secara benar, jelas dan jujur, memisahkan lokasi, tempat dan alat penyembelihan, pengolahan, penyimpanan, pengemasan, pendistrbusian, penjualan dan penyajian antara produk halal dan tidak halal.

2) Memiliki penyedia halal.

3) Dan melakukan perubahan komposisi bahan kepada Badan Penyelenggara Jaminan Produk Halal (BPJPH)

Kemudian setelah memperoleh sertifikat halal, pelaku usaha wajib :

1) Mencantumkan label halal terhadap produk yang telah mendapat sertifikat halal.

2) Menjaga kehalalan produk yang telah memperoleh sertifikat halal.

3) Memisahkan lokasi, tempat dan penyembelihan, alat pengolahan, penyimpanan, pengemasan, pendistribusian, penjualan, dan penyajian antara produk halal dan tidak halal.

4) Memperbaharui sertifikat halal jika masa berlaku sertifikat halal berakhir, dan melaporkan perubahan komposisi bahan kepada BPJPH.

Pelaku usaha yang tidak melakukan kewajibannya setelah memperoleh sertifikat halal, dikenai sanksi administratif berupa:

1) Peringatan tertulis.

2) Denda administratif.

3) Pencabutan sertifikat halal.

Mengenai kewajiban mencantumkan label halal oleh pihak yang telah mendapatkan sertifikat halal perlu diketahui bahwa bentuk label halal ini ditetapkan oleh BPJPH (Badan Penyelenggara Jaminan Produk Halal) dan berlaku nasional.

Pelaku usaha yang telah memperoleh sertifikat halal wajib mencantumkan label halal pada:

1) Kemasan produk.

2) Bagian tertentu dari produk.

3) Tempat tertentu pada produk.

Pencantuman label halal harus mudah dilihat dan dibaca serta tidak mudah dihapus dilepas dan dirusak. Perlu diketahui bahwa pelaku usaha yang tidak menjaga kehalalan produk yang telah memperoleh sertifikat halal dipidana dengan pidana penjara paling lama 5 
DEIFGA LATA

Jurnal Ilmu Hukum

FAKULTAS HUKUM UMSU
Pengawasan Dan Koordinasi...(Rabiah Z Harahap)

Volume 3 Nomor 1, Januari-Juni 2018, 108-118 DOI: $\underline{\text { https://doi.org/10.30596/dll.v3i1.3145 }}$

tahun atau pidana denda paling banyak 2 Milyar.

Produk dari bahan yang diharamkan

Adapun yang termasuk bahan yang diharamkan menurut Undang-undang Produk halal yaitu:

1) Bahan yang berasal dari hewan meliputi:

a) Bangkai.

b) Darah .

c) Babi dan/atau.

d) Hewan yang disembelih tidak sesuai dengan syariat.

2) Bahan yang berasal dari tumbuhan pada dasarnya halal kecuali memabukkan dan/atau membahayakan kesehatan bagi orang yang mengkonsumsinya.

3) Bahan yang berasal dari mikroba dan bahan yang dihasilkan melalui proses kimiawi, proses biologi atau proses rekayasa genetik. Diharamkan jika proses pertumbuhan dan/atau pembuatannya tercampur, terkandung, dan/atau terkontaminasi dengan bahan yang diharamkan.

Pelaku usaha yang memproduksi produk dari bahan yang berasal dari bahan yang diharamkan dikecualikan dari mengajukan permohonan sertifikasi halal. Pelaku usaha tersebut wajib mencantumkan keterangan tidak halal pada produk. Jika pelaku usaha tidak mencantumkan keterangan tidak halal, dikenai sanksi administratif berupa:

a) Teguran lisan

b) Peringatan Tertulis

c) Denda administratif.

Disini masyarakat tidak perlu khawatir karena bagi produk yang halal harus ada label halalnya, sebaliknya produk yang berasal dari bahan dari yang diharamkan harus mencantumkan keterangan tidak halal.

\section{Label Halal dan Perlindungan Konsumen.}

Label pangan adalah setiap keterangan mengenai pangan yang berbentuk gambar, tulisan, kombinasi keduanya atau bentuk lain yang disertakan pada pangan, dimasukkan ke dalam, ditempelkan pada atau merupakan bagian kemasan pangan (Pasal 1 angka 3 Peraturan Pemerintah Nomor 69 Tahun 1999). Selain dari label informasi tentang produk dapat diperoleh dari iklan.

Iklan pangan adalah setiap keterangan atau pernyataan mengenai pangan dalam bentuk gambar, tulisan atau dalam bentuk lain yang dilakukan dengan berbagai cara untuk pemasaran dan/atau perdagangan (Pasal 1 angka 4 Peraturan Pemerintah Nomor 69 Tahun 1999). Secara normatif empiris label dan iklan pangan memiliki beberapa fungsi: Pertama Sebagai sumber informasi. Label pangan dan iklan merupakan sumber informasi bagi konsumen tentang suatu produk pangan karena konsumen tidak dapat langsung bertemu dengan pelaku usahanya. Pelaku usaha dapat saja memasukkan unsur-unsur upaya memikat atau membujuk konsumen untuk membeli produknya. Akan tetapi label dan iklan tidak diperkenankan hanya sekedar menginformasikan sesuatu yang hanya menguntungkan dari sisi pelaku usaha. Informasi yang benar, jelas dan jujur harus disampaikan kepada konsumen termasuk higenis dan kehalalannya (Pasal 4 Undang-Undang Nomor 8 Tahun 1999 tentang Perlindungan Konsumen).

Kedua Label dan iklan pangan dapat digunakan sebagai bahan pertimbagan bagi 


\section{DE IFGA LATA}

Jurnal Ilmu Hukum

FAKULTAS HUKUM UMSU
Pengawasan Dan Koordinasi...(Rabiah Z Harahap)

Volume 3 Nomor 1, Januari-Juni 2018, 108-118 DOI: $\underline{\text { https://doi.org/10.30596/dll.v3i1.3145 }}$

konsumen untuk menentukan pilihan. Konsumen kritis tentu saja terdahulu membaca label dan iklan pangan dengan cermat. Teliti dan melakukan perbandingan dengan produk lain dari segi komposisi, berat bersih, harga dan lain-lain sebelum membeli dan menjatuhkan pilihan (Pasal 4 Undang-Undang Nomor 8 Tahun 1999 tentang Perlindungan Konsumen).

Ketiga Label dan iklan dapat digunakan sebagai sarana mengikat transaksi. Label dan iklan harus mengikat. Segala sesuatu yang diinformasikan dalam label dan yang dijanjikan dalam iklan, harus dapat dibuktikan kebenarannya. Iklan harus legal, terukur, jujur dan objektif. Pelaku usaha harus bersedia dituntut apabila ternyata label dan iklannya tidak terbukti benar (Pasal 8, 9, 10, 11, 12, 13, 14, 15, 16 dan 17 Undang-Undang Nomor 8 Tahun 1999 tentang Perlindungan Konsumen 8 Tahun 1999 tentang Perlindungan Konsumen).

Dasar penetapan labelisasi merupakan perwujudan pemenuhan hak masyarakat untuk mendapatkan produk yang dipilihnya. Khususnya agar konsumen terbebas dari produk yang tidak mengandung bahan, atau perlakuan yang tidak diijinkan agama (Haram). Perkembangan yang lahir dari teknologi pengolahan, pengemasan dan pemasaran produk barang dan/atau jasa dewasa ini menyebabkan sistem pelabelan mutlak diperlukan. Tanpa label (tanda) masyarakat sulit mengenali bahan baku, komposisi dan proses yang dilalui oleh produk tersebut. Namun demikian perlu digarisbawahi bahwa labelisasi hanya satu bagian saja dari sistem pengawasan. Produk secara keseluruhan. Label hanya sekedar informasi yang diberikan untuk pemasaran, dan bukan proses produksi.

Lebih jauh dari itu dalam mekanisme pasar sistem bebas, labelisasi dapat dipergunakan sebagai instrumen untuk merangsang pasar. Oleh karena itu sistem pengawasan produk melalui labelisasi akan berfungsi untuk mengoreksi pasar dengan cara memberikan informasi kepada masyarakat.

Peraturan perundang-undangan Pasal 30 ayat 1 Undang-Undang Nomor 7 Tahun 1996 Tentang Pangan Menyebutkan "Setiap orang memproduksi atau memasukkan ke dalam wilayah Indonesia pangan yang dikemas untuk diperdagangkan wajib mencantumkan label pada di dalam atau dikemasan pangan".

Selanjutnya ayat 2 huruf e label sebagaimana dimaksudkan ayat 1 memuat sekurangkurangnya mengenai keterangan tentang halal. Penjelasan tentang Pasal 30 ayat 2 huruf e menyebutkan "Keterangan halal untuk suatu produk pangan sangat penting untuk masyarakat Indonsia yang mayoritas memeluk agama Islam. Namun demikian, pencantumannya pada label pangan baru merupakan kewajiban apabila setiap orang memproduksi pangan dan atau memasukkan pangan kedalam wilayah Indonesia untuk diperdagangkan, menyatakan bahwa pangan yang bersangkutan adalah halal bagi umat Islam. Adapun keterangan yang dimaksudkan agar masyarakat terhindar dari mengonsumsi pangan yang tidak halal (haram)".

Peraturan organik Undang-Undang Nomor 18 Tahun 2012 tentang Pangan, yakni Peraturan Pemerintah Nomor 69 Tahun 1999 tentang Label dan Iklan Pangan, Pasal 10 ayat 1 menyebutkan "Setiap orang yang memproduksi atau memasukkan kedalam wilayah Indonesia pangan yang dikemas untuk diperdagangkan dan menyatakan bahwa pangan tersebut halal bagi umat Islam, bertanggung jawab atas pernyataan tersebut dan wajib mencantumkan keterangan atau tulisan halal pada label”.

Pasal 11 ayat 1 Peraturan Pemerintah Nomor 9 Tahun 1999 menyatakan bahwa "Setiap orang yang memproduksi atau memasukkan kedalam wilayah Indonesia pangan yang dikemas untuk diperdagangkan wajib memeriksa terlebih dahulu pangan tersebut pada lembaga 


\section{DE IFGA LATA}

Jurnal Ilmu Hukum

FAKULTAS HUKUM UMSU
Pengawasan Dan Koordinasi...(Rabiah Z Harahap)

Volume 3 Nomor 1, Januari-Juni 2018, 108-118 DOI: $\underline{\text { https://doi.org/10.30596/dll.v3i1.3145 }}$

pemeriksa yang telah diakreditasi atau sesuai dengan peraturan perundang-undangan yang berlaku".

Di dalam penjelasan Pasal 11 ayat 1 disebutkan bahwa pencantuman tulisan halal pada dasarnya bersifat sukarela. Namun setiap orang yang memproduksi dan memasukkan pangan ke dalam wilayah Indonesia untuk diperdagangkan menyatakan sebagai produk yang halal sesuatu ketuntuan ia wajib mencantumkan ketentuan halal pada label produknya.

Pasal 8 ayat 1 huruf h Undang-Undang Nomor 8 Tahun 1999 tentang Perlindungan Konsumen menegaskan "Pelaku usaha dilarang memproduksi dan/atau jasa yang tidak mengikuti ketentuan berproduksi secara halal, sebagaimana pernyataan 'halal' yang dicantumkan pada label". Secara normatif peraturan hukum yang mengatur sertifikasi halal bagi produk pangan olahan paling tidak mendapat pengakuan kuat dan kokoh didalam ketiga hukum positif tersebut diatas. Namun demikian, pencantuman penulisan halal itu pada dasarnya hanya bersifat sukarela semata, hingga secara yuridis belum ada peraturan hukum positif Indonesia yang mewajibkan para produsen pangan olahan untuk mencantumkan label halal (atau haram) pada setiap produknya.

Secara sosiologis peraturan hukum positif kewajiban sertifikasi halal (atau haram) diperlukan sebagai proteksi bagi konsumen Indonesia yang mayoritas Islam. Dengan adanya kewajiban sertifikasi halal (atau haram) tentu saja dapat menghindarkan timbulnya keraguan umat Islam sekaligus memberikan ketenteraman dan keyakinan bahwa pangan yang dikonsumsinya memang aman dari segi agama (keamanan spiritual).

Selama ini banyak produk pangan olahan yang tidak memiliki sertifikat halal (atau haram), sehingga tidak diketahui halal atau haramnya. Yang pasti dengan adanya sertifikasi halal (atau haram) kontroversi yang pernah terjadi seperti pada kasus Aji-No-Moto, Indomie mengandung lemak babi, dan kasus Bika Ambon dapat dieliminir.

Dengan merujuk ketentuan Pasal 4 huruf a dan c Undang-Undang Nomor 8 Tahun 1999 bahwa konsumen berhak atas informasi yang benar, jelas dan jujur mengenai kondisi dan jaminan suatu barang, serta konsumen berhak untuk memilih, perlu diwajibkan sertifikasi yang berisi memberi ruang dan kesempatan bagi kelompok masyarakat yang tidak mengonsumsi barang yang haram.

Tentunya yaitu berupa kewajiban bagi produsen pangan olahan untuk memberikan informasi yang benar kepada konsumen, apakah produk pangan olahannya itu mengandung zat haram atau tidak. Berdasarkan itu seharusnya pencantuman label halal pada setiap produk pangan semestinya dijadikan hukum wajib diserati sanksi, sehingga tidak dapat disimpangi oleh pelaku usaha. Oleh sebab itu, dari 1500 -an produk pangan ternyata hanya $10 \%$ yang mencantumkan label halal dan mengantongi sertifikat halal yang dikeluarkan oleh Majelis Ulama Indonesua (MUI), sisanya 90\% belum mencantumkan label halal, hingga masih sangat diragukan kehalalannya.

\section{Pengawasan dan penggunaan sertifikat halal.}

Kesadaran produsen untuk mencantumkan label halal pada produknya adalah keharusan, hal ini dikarenakan mayoritas penduduk di Indonesia adalah ummat Islam, hal ini dikarenakan mayoritas jumlah penduduk di Indonesia adalah ummat Islam. Berdasarkan insting bisnis inilah memunculkan praktek-praktek penggunaan label halal palsu tanpa prosedur halal yang disyaratkan. Dalam artian bahwa produk yang beredar memiliki label 
DEIFGA LATA

Jurnal Ilmu Hukum

FAKULTAS HUKUM UMSU
Pengawasan Dan Koordinasi...(Rabiah Z Harahap)

Volume 3 Nomor 1, Januari-Juni 2018, 108-118 DOI: $\underline{\text { https://doi.org/10.30596/dll.v3i1.3145 }}$

halal, namun tidak memiliki sertifikat halal untuk menyesatkan konsumen agar memakai produk produsen tersebut.

Produk haram dengan label halal yang beredar di masyarakat akan mempunyai dampak negatif, tidak hanya berpengaruh pada perusahaan itu sendiri tetapi juga pertumbuhan ekonomi masyarakat dan bangsa pada umumnya. Bagi seorang muslim, makanan dan minuman erat sekali kaitannya dengan ibadah. Terkait dengan penggunaan label halal secara illegal tersebut, mengharuskan adanya pengaturan yang secara ketat mengatur tentang label halal secara khusus.

Dalam hal pengawasan sertifikat halal LPPOM MUI hanya menyaratkan perusahaan wajib menandatangani perjanjian untuk menerima tim inspeksi mendadak LPPOM MUI sewaktu-waktu dan perusahaan berkewajiban menyerahkan laporan audit internal setiap 6 bulan setelah terbitnya sertifikat halal.

Padahal banyak produk-produk yang beredar tengah masyarakat menggunakan label halal tapi tidak memiliki sertifikat halal. Bukankah hal tersebut juga harus ditekan dan diawasi perkembangannya karena penggunaan label halal secara illegal merupakan tindak pidana ${ }^{6}$. Untuk itu pula target pengawasan pada produk makanan tidak hanya ditujukan pada produk makanan yang telah terdaftar, namun lebih jauh lagi pengawasan dilakukan kepada produk makanan yang belum terdaftar kehalalannya. Untuk mengawasi produk makanan tersebut, pemerintah berwenang melakukan pemeriksaan dalam hal terdapat dugaan terjadinya pelanggaran hukum di bidang pangan dengan cara:

a) Memasuki setiap tempat yang digunakan dalam kegiatan atau proses produksi, penyimpanan, pengangkutan dan perdagangan pangan untuk memeriksa, meneliti dan mengambil contoh pangan dan segala sesuatu yang diduga digunakan dalam kegiatan produksi, penyimpanan, pengangkutan dan/atau perdagangan pangan.

b) Menghentikan, memeriksa dan mencegah setiap sarana angkutan yang diduga ataupun patut diduga digunakan dalam pengangkutan pangan serta mengambil dan memeriksa contoh pangan.

c) Membuka dan meneliti setiap kemasan pangan.

d) Memeriksa setiap buku, dokumen atau catatan lain yang diduga memuat keterangan mengenai kegiatan produksi, penyimpanan, pengangkutan dan/atau perdagangan pangan termasuk menggandakan atau mengutip keterangan tersebut.

e) Memerintah untuk memperlihatkan izin usaha atau dokumen lain sejenis (Zulham, 24: 2013)

Berdasarkan hasil pemeriksaan tersebut patut diduga merupakan tindak pidana dibidang pangan, segera dilakukan tindakan penyidikan oleh penyidik berdasarkan peraturan perundang-undangan yang berlaku.

Dalam rangka pengawasan, maka pemerintah perlu mengadakan pengaturan lebih lanjut sebagai berikut :

a) Departemen Agama dalam hal petunjuk tentang bahan baku, bahan tambahan, proses produksi dan peredaran makanan halal.

b) Departemen Pertanian dalam proses penyediaan bahan baku yang berasal dari hewan dan tumbuhan.

c) Departemen Perindustrian dalam hal pembinaan industri. 
DEIFGA LATA

Jurnal Ilmu Hukum

FAKULTAS HUKUM UMSU
Pengawasan Dan Koordinasi...(Rabiah Z Harahap)

Volume 3 Nomor 1, Januari-Juni 2018, 108-118 DOI: $\underline{\text { https://doi.org/10.30596/dll.v3i1.3145 }}$

d) Departemen Kesehatan dalam hal penetapan persyaratan yang berhubungan dengan kesehatan dan periklanan.

e) Departemen Perdagangan dalam hal penetapan persyaratan import bahan baku, bahan tambahan dan bahan makanan penolong makanan halal.

Pengawasan oleh pemerintah dilakukan dengan cara preventif dan pengawasan khusus:

a) Pengawasan preventif dilakukan menteri agama dan dapat bekerjasama dengan menteri yang terkait ${ }^{8}$.

b) Pengawasan di lab produk tentang jaminan produk halal dilakukan oleh menteri agama.

c) Pengawas khusus dalam hal tertentu dilakukan oleh meteri agama bersama-sama oleh menteri yang terkait.

BPJPH dan kementerian dan/atau lembaga terkait yang memiliki kewenangan pengawasan JPH dapat melakukan pengawasan secara sendiri-sendiri atau bersama-sama. Pengawasan JPH dengan kementerian atau lembaga terkait dilaksanakan sesuai dengan ketentuan perundang-undangan. Ketentuan lebih lanjut mengenai pengawasan diatur dalam peraturan pemerintah. Peran serta masyarakat dalam pengawasan produk halal atau jaminan produk halal (JPH) diharapkan dapat membantu pemerintah dalam hal ini BPJPH dan kementerian terkait. Dalam Undang-Undang Nomor 23 tahun 2013 tentang Jaminan Produk Halal telah tertuang sebagaimana yang dapat dilakukan masyarakat dalam melakukan pengawasan terhadap beredarnya produk halal dan tidak halal, yakni :

a) Masyarakat dapat berperan serta dalam penyelenggaraan JPH.

b) Peran serta masyarakat dapat berupa:

1) Melakukan sosialisasi mengenai JPH

2) Mengawasi produk dan produk halal yang beredar

c) Peran serta masyarakat berupa pengawasan produk dan produk halal yang berddar sebagaimana yang dimaksud pada ayat 2 huruf $b$ berbentuk pengaduan atau pelaporan ke BPJH. Masyarakat yang berperan serta dalam penyelenggaraan dan pengawasan JPH akan mendapatkan penghargaan yang diberikan oleh BPJPH.

Lahirnya Peraturan Pemerintah Nomor 58 Tahun 2001 tentang Pembinaan dan Pengawasan Penyelenggaraan Pembinaan Konsumen, menjadi kabar gembira bagi para konsumen di Indonesia karena peraturan pemerintah tersebut telah melibatkan peran pemerintah dalam melakukan pengawasan sebagaimana masyarakat dan lembaga perlindungan konsumen swadaya masyarakat, kendatipun dengan objek pengawasan yang sedikit berbeda. Peraturan Pemerintah Nomor 58 Tahun 2001 tentang Penyelanggaran Perlindungan Konsumen merumuskan :

a) Pengawasan oleh pemerintah dilakukan terhadap pelaku usaha dalam memenuhi standar mutu produksi barang dan/atau jasa, pencantuman label dan klausula baku, serta pelayanan purna jual barang dan/atau jasa.

b) Pengawasan sebagaimana dimaksud dalam ayat 1 dilakukan dalam proses produksi, penawaran, promosi, pengiklanan, dan penjualan barang atau jasa.

c) Hasil pengawasan sebagaimana dimaksud dalam ayat 2 dapat disebarluaskan kepada masyarakat.

d) Ketentuan mengenai tata cara pengawasan sebagai mana dimaksud dalam ayat 1 ditetapkan oleh menteri dan/atau menteri tekhnis terkait bersama-sama atau sendiri-sendiri sesuai dengan bidang dan tugas masing-masing. 
DEIFGA LATA

Jurnal Ilmu Hukum

FAKULTAS HUKUM UMSU
Pengawasan Dan Koordinasi...(Rabiah Z Harahap)

Volume 3 Nomor 1, Januari-Juni 2018, 108-118 DOI: $\underline{\text { https://doi.org/10.30596/dll.v3i1.3145 }}$

Ketentuan pengawasan yang diperankan oleh masyarakat tersebut praktis sama dengan ketentuan pengawasan yang diperankan oleh lembaga perlindungan konsumen swadaya masyarakat (LPKSM) hanya saja pengawasan yang diperankan oleh LPKSM mensyaratkan bahwa penelitian, pengujian dan survei yang dilakukan harus didasarkan pada adanya dugaan bahwa produk tersebut tidak memenuhi unsur keamanan, kesehatan, kenyamanan, dan keselamatan konsumen. Peraturan Pemerintah Nomor 58 Tahun 2001 tentang Penyelanggaran Perlindungan Konsumen merumuskan bahwa :

a) Pengawasan oleh LPKSM dilakukan oleh barang dan/atau jasa yang beredar di pasar.

b) Pengawasan sebagaimana yang dimaksud oleh ayat 1 dilakukan dengan cara penelitian, pengujian dan/atau survei.

c) Aspek pengawasan meliputi pemuatan informasi tentang resiko penggunaan barang yang diharuskan, pemasangan label, pengiklanan dan lain-lain yang disarankan berdasarkan ketentuan peraturan perundang-undangan dan kebiasaan dalam praktek dunia usaha.

d) Penelitian, pengujian dan/atau suvei sebagaimana yang dimaksud dalam ayat 2 dilakukan terhadap barang dan/atau jasa yang diduga tidak memenuhi unsur keamanan, kesehatan, kenyamanan dan keselamatan konsumen.

e) Hasil pengawasan sebagaimana dimaksud dalam ayat 2 dapat disebarluaskan kepada masyarakat dan dapat disampaikan kepada menteri dan menteri tekhnis.

\section{KESIMPULAN DAN SARAN Kesimpulan}

Di dalam Undang-undang perlindungan konsumen mengatakan bahwa usaha dilarang memproduksi dan/atau memperdagangkan barang atau jasa yang tidak mengikuti ketentuan berproduksi secara halal (Undang-Undang Nomor 23 Tahun 2014 Tentang Jaminan Produk Halal). Produk halal adalah produk yang telah dinyatakan halal sesuai dengan syariat islam, pengawasan pada penggunaan sertifikasi halal LPPOM MUI mensyaratkan perusahaan wajib menandatangani perjanjian untuk menerima tim inspeksi mendadak LPPOM MUI sewaktu waktu dan perusahaan berkewajiban menyerahkan laporan audit internal setiap 6 bulan setelah terbitnya sertifikasi halal.

\section{Saran}

Diharapkann pengawasan pada penggunaan sertifikasi halal LPPOM MUI mensyaratkan perusahaan wajib menandatangani perjanjian untuk menerima tim inspeksi mendadak LPPOM MUI sewaktu waktu dan perusahaan berkewajiban menyerahkan laporan audit internal setiap 6 bulan setelah terbitnya sertifikasi halal guna menjamin koordinasi sertifikasi halal berjalan dengan baik. 
Jurnal Ilmu Hukum

FAKULTAS HUKUM UMSU
Pengawasan Dan Koordinasi...(Rabiah Z Harahap)

Volume 3 Nomor 1, Januari-Juni 2018, 108-118 DOI: $\underline{\text { https://doi.org/10.30596/dll.v3i1.3145 }}$

\section{DAFTAR PUSTAKA}

Marzuki, Peter Mahmud. (2011). Penelitian Hukum. Jakarta: Kencana Prenada Media Group.

Seokanto, Sorejono., \& Muji, Sri. (2003). Penelitian Hukum Normatif Suatu Tinjauan Singkat. Jakarta: Rajawali Pers.

Seokanto, Sorejono., \& Muji, Sri.(1996). Pengantar Penelitian Hukum. Jakarta: UI Press.

Undang-undang Republik Indonesia, Undang-undang Nomor 33 Tahun 2014 Tentang Jaminan Produk Halal

Undang-undang Republik Indonesia, Undang-undang Nomor 7 Tahun 1996 Tentang Pangan

Undang-undang Republik Indonesia, Undang-undang Nomor 9 Tahun 1999 Tentang Perlindungan Konsumen

Zulham. (2013). Hukum Perlindungan Konsumen. Jakarta: Kencana Prenada Media Grup. 